\title{
Electoral competition in Europe's new tripolar political space: Class voting for the left, centre-right and radical right
}

\author{
DANIEL OESCH${ }^{1} \&$ LINE RENNWALD ${ }^{2}$ \\ ${ }^{1}$ Life Course and Inequality Research Centre (LINES), University of Lausanne, Switzerland; ${ }^{2}$ European \\ University Institute, San Domenico di Fiesole, Italy
}

\begin{abstract}
The rise of the radical right fundamentally changes the face of electoral competition in Western Europe. Bipolar competition is becoming tripolar, as the two dominant party poles of the twentieth centurythe left and the centre-right - are challenged by a third pole of the radical right. Between 2000 and 2015, the radical right has secured more than 12 per cent of the vote in over ten Western European countries. This article shows how electoral competition between the three party poles plays out at the micro level of social classes. It presents a model of class voting that distinguishes between classes that are a party's preserve, classes that are contested strongholds of two parties and classes over which there is an open competition. Using seven rounds of the European Social Survey, it shows that sociocultural professionals form the party preserve of the left, and large employers and managers the preserve of the centre-right. However, the radical right competes with the centre-right for the votes of small business owners, and it challenges the left over its working-class stronghold. These two contested strongholds attest to the co-existence of old and new patterns of class voting. Old patterns are structured by an economic conflict: Production workers vote for the left and small business owners for the centre-right based on their economic attitudes. In contrast, new patterns are linked to the rise of the radical right and structured by a cultural conflict.
\end{abstract}

Keywords: cleavage; radical right; social class; voting; working class

\section{Introduction}

The electoral rise of radical right-wing parties has led to the formation of three political poles of increasingly similar size in Western Europe. In a growing number of countries, the two dominant poles of the twentieth century - the political parties of the left and the centreright - are challenged by a third pole made up by the radical right. This emergence of a tripolar political space has gone along with the electoral decline of the mainstream parties of the left and the right - the social democrats and Christian democrats (Martin 2013). While the political space had crystallised into a clear triangular configuration by 2000 in only a few countries - most notably France (Grunberg \& Schweisguth 2003; Bornschier \& Lachat 2009) - it had quickly become the rule rather than the exception across Western Europe by 2017.

The argument of a tripolar political space is not new. It has been made for party families' ideologies (e.g., Kriesi et al. 2006, 2008) and voters' attitudes (e.g., Kriesi et al. 2008; Van Der Brug \& Van Spanje 2009). We develop this argument further by uncovering the underlying structural basis for this tripolar division. We argue that, in the tripolar political space, the three poles are in competition with each other over different occupational segments of the electorate. The left competes with the radical right for the support of the working class, notably production workers, whereas the centre-right competes with the radical right for 
the votes of the old middle class made up of small business owners. In turn, the left and the centre-right are in competition for the support of the growing salaried middle class.

The rise of the radical right has thus not only shifted electoral competition from a bipolar to a tripolar setting, but has also triggered a process of realignment between sociodemographic groups and political parties and thereby led to a renaissance of class voting (Rydgren 2013). Contrary to the thesis that European societies are marked by 'an increasing homogeneity of experiences' (Katz \& Mair 2009: 758) where class holds little electoral appeal (Franklin et al. 2009), we provide comparative evidence that class voting in the tripolar political space is very much alive and kicking. A crucial piece in this puzzle is the proletarianisation of the radical right's electorates (Oesch 2008a; Bornschier \& Kriesi 2013).

A tripolar configuration presupposes that there are at least two dimensions of political conflict. A first economic dimension separates the mainstream left from the mainstream right, whereas a second cultural dimension pits the radical right against both the established left and right (Kitschelt 1994). Our ambition is to locate occupational classes in this twodimensional space and to draw the sociostructural map of electoral competition between the three party blocs.

We focus on the political demand-side of voters and analyse the micro-foundations of electoral competition for nine West European countries where the political space was tripolar for part - or all - of the period between 2000 and 2015: Austria, Belgium, Denmark, Finland, France, the Netherlands, Norway, Sweden and Switzerland. Our empirical analysis takes full advantage of the European Social Survey (ESS) ${ }^{1}$ by merging the Survey's seven rounds from 2002 to 2014 into a single dataset. We compare our findings for the tripolar political space in time - to class voting before the radical right emerged - and in space - to class voting in countries without a radical right pole. We define a political space to be tripolar if each of the three poles, and notably the radical right, obtains more than 12 per cent of the national vote. This was the case for over 20 national elections in Western Europe between 2000 and 2015.

In this article, we first develop a model that shows how parties compete for classes in the tripolar political space. We then define the party poles, present the three poles' electoral size, and discuss our measures for class and attitudes. We then provide empirical results on class voting and show how the class effect is altered once we account for differences in voters' economic and cultural attitudes. The article's conclusion summarises our main findings.

\section{Parties in the tripolar political space}

A political system can only accommodate three different poles if it is based on at least two dimensions. Several authors argue, theoretically and empirically, that voters' preferences are structured along two axes (Bornschier 2010; Hooghe et al. 2002; Kitschelt 1994; Kriesi et al. 2008). A first economic axis goes from a socialist to a capitalist end and plots supporters of income redistribution against supporters of free market solutions. A second cultural axis relates to the politics of identity and runs from a libertarian end to a traditional end. While the first axis is about materialist needs and the market, the second is about belonging to a community.

We argue that three party blocs can usefully be distinguished within this political space based on parties' ideology: the left, the centre-right and the radical right. Parties of the left 
include social democrats, communists, greens and the new left, which combine an economic position in favour of a strong welfare state with a culturally liberal stance on migration and multiculturalism. Parties of the centre-right comprise Christian democrats, liberals and conservatives, which oppose the left over state intervention in the economy, but share a positive view of cultural issues such as European integration and international migration. The radical right includes right-wing populist parties for whom the economic axis is of subordinate importance (Mudde 2007) as they abandoned their initial neoliberal stance of the 1980s (De Lange 2007) and blurred their socioeconomic positions in order to attract broader support (Afonso 2015; Rovny 2013). What sets the radical right apart as a third pole is its challenge of both the left and the centre-right over cultural issues by strongly opposing immigration, multiculturalism and European integration.

The classification of party families into three poles may meet with several objections. A first concern is that it lumps together different party families. Both the left and the centreright may be seen as internally divided over cultural issues between the libertarian greens and more conventional social democrats, on the one hand, and the liberal centrist parties and the conservatives on the other. A second objection does not focus on internal divisions within the poles, but considers, on the contrary, that the radical right is not sufficiently diverse from the centre-right, but simply expands the right-wing bloc (Bale 2003). It should thus best be seen within the unidimensional left-right opposition of parties (Van Der Brug \& Van Spanje 2009).

Our typology of three party families disagrees with both objections. We follow the argument that the rise of the new left has resulted in a rapprochement on cultural issues within the left between the social democrats and green parties. In contrast, the rise of the radical right has led to a split within the right between the economically liberal and culturally moderate centre-right and the culturally authoritarian radical right (Cochrane 2013; Kriesi et al. 2015: 3).

Our litmus test for the three poles is whether parties of a given pole share a common ideological basis that makes them natural coalition partners for government formation. This seems to be the case for social democrats, greens and communists on the left, as well as for Christian democrats, liberals and conservatives on the centre-right. In contrast, grand coalitions between the left and the right are the exception, and the participation of radical right parties in government even more exceptional - 'a rarity in Western Europe' (Mudde 2013:5). Still, we take these objections seriously and our empirical analysis also shows results for class voting by the largest party within each party pole.

Another concern is that the radical right may be too small to constitute a pole in its own right. A brief look at electoral scores helps us to discard the argument at this stage. Between 2000 and 2015, parties of the radical right obtained more than 20 per cent of the popular vote in two or more national elections in Austria, Norway and Switzerland - and more than 15 per cent in two national elections in Finland, France and the Netherlands.

In parallel to the rise of the radical right, we observe the electoral decline of the mainstream parties of the left and right. Averaged over 15 West European countries, social democrats received the constant support of 30 per cent of voters between 1945 and 1980, before seeing their electoral share fall to 28 per cent in 1991-2000 and to 25 per cent in 2006-2010 (Martin 2013: 544). Likewise, Christian democrats saw their proportion of the national vote drop from 23 per cent in the 1950 s to 20 per cent in the 1970 s and 14 per cent 
in 2006-2010 (Martin 2013:544). Since 1990, the largest gains were made by the radical right. While it is the smallest pole in the triangular political space, it is by no means insignificant and the electoral catch-up process in Europe still seems to be under way.

\section{Voters and classes in the tripolar political space}

The rise of the radical right has not only provided the decisive impetus for the formation of a third pole and hence of a tripolar party space. In addition, it has also contributed - together with the rise of the new left and green parties a decade earlier - to a process of electoral realignment where old ties between classes and parties have loosened and been replaced by new ties. The electoral competition in the tripolar space is therefore not a mere conflict over values, but also anchored in the occupational structure. The three poles compete for the votes of different classes and, given the right analytical tools, the micro-foundations of this new form of class voting should clearly emerge. We thus consider claims about the classless society and the death of class voting as premature (Franklin et al. 2009).

We define 'class voting' as the presence of systematic links between voters' class location - their position in the labour market - and the parties they support. Which classes relate to which parties is then an empirical question, with workers voting for the left being just one instance of class voting (Oesch 2008b). Furthermore, we argue that voters' class positions may affect both their economic and cultural attitudes. In their job, people not only make a living, but are also exposed to experiences of autonomy and control, and to a specific set of social interactions with superiors, colleagues, clients, patients or pupils. These work experiences likely contribute to shaping voters' values on both economic and cultural issues - and may result in systematic differences in class voting (Kitschelt 2010: 666; Oesch 2013: 32).

A concern is that individuals choose an occupation (and end up in a given class) because of pre-existing preferences and that social class is thus endogenous to political attitudes. The empirical disentanglement of the two mechanisms (class $\rightarrow$ attitudes versus attitudes $\rightarrow$ class) is difficult. While self-selection certainly plays a role, Kitschelt and Rehm (2014) convincingly argue that in industrialised societies where citizens spend over a third of their waking time at work, it is unlikely that what they do in their job does not affect their orientation in the social world.

Yet of course, individuals' identities are not only forged by their occupation and class, but also by religion, language or nationality. Party choice is then determined by the identity that is most salient - and also depends on parties' efforts to articulate different identities and mobilise around particular conflicts (Bornschier 2010: 58-59).

In order to draw the map of class voting in the tripolar political space, we distinguish three types of relationships that link classes to the party poles: (1) some classes are the preserve of one particular pole; (2) some classes are the contested stronghold of two different poles; and (3) all three poles are in open competition over some classes. In a party preserve, a single party pole receives above-average electoral support from a class, whereas the two other poles obtain below-average support from the same class. In a contested stronghold, two party poles receive above-average electoral support from a class, and the last pole receives below-average support from the same class. In open competition, classes do not vary in their party choice from the average voter. ${ }^{2}$ 


\section{Preserves $\longrightarrow$ Contested strongholds $\longrightarrow$ Open competition $\quad---\rightarrow$}

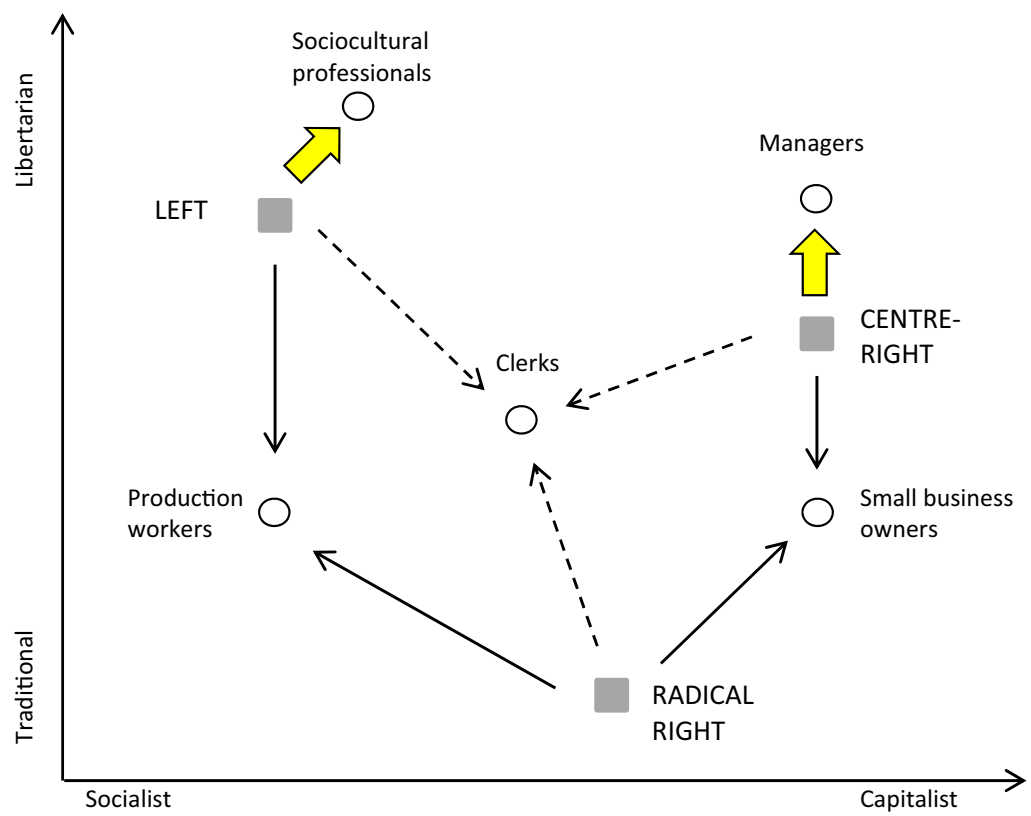

Figure 1. A model of party poles and class-party links in a two-dimensional political space. [Colour figure can be viewed at wileyonlinelibrary.com]

These three types of relationships provide a useful tool to grasp both breaks and continuities in class voting and to accommodate situations in which party dominance over one class has weakened without completely disappearing. Depending on the countries studied, research on class voting shows the resilience of traditional forms of class voting (Evans \& Tilley 2012) or emphasises the emergence of new patterns of class voting (e.g., Ivarsflaten 2005).

We argue that the two traditional party blocs of the left and the centre-right each keep one class as its preserve: the left is the uncontested champion among professionals in health care, education, social welfare and the media (henceforth: sociocultural professionals), whereas the centre-right benefits from the strong endorsement of large employers, managers and liberal professionals. The two mainstream poles are challenged by the radical right over two of their traditional strongholds: the left faces strong competition over the working class, whereas the centre-right struggles to keep the votes of the old middle class of small business owners. Finally, there is open competition between the three poles for the votes of two classes, technical professionals and technicians (henceforth: technical specialists) as well as office clerks (such as secretaries and receptionists).

Our model is shown in Figure 1 and locates the position of party poles and classes within the two-dimensional political space. This model thus depicts how we expect the electoral competition over a given class to play out. We begin with liberal professionals, 
large employers and managers. Their privileged location within the class structure not only leads them to adopt market-liberal economic preferences, but also leaves them undaunted by globalisation, immigration and multiculturalism. Given their preferences for market solutions and cultural liberalism, the centre-right should be in a clear pole position for the vote of these classes.

In contrast, sociocultural professionals mostly work as wage-earners in the public sector and likely favour a strong welfare state and income redistribution (Gingrich \& Häusermann 2015). More importantly, as their work process mainly consists of social interactions teaching, nursing, counselling - and requires tolerance for cultural diversity, they should have markedly libertarian cultural preferences (Kitschelt \& Rehm 2014: 6-7; Kriesi 1998: 169). Ever since the rise of the new social movements that mobilised around postmaterialist issues in the 1970s and 1980s, sociocultural professionals should be the preserve of the left.

While the rise of the radical right has by no means challenged the left's predominance among sociocultural professionals, it has led to a bitter contest over the traditional leftist stronghold of the working class - notably production workers. They were not only hit by de-industrialisation, mass unemployment and trade union decline, but also often lost out in the economic reforms of Third Way social democratic governments. Not surprisingly, they do not share in the Third Way optimism about the knowledge society and have responded with increased electoral abstention (Arndt 2013).

The waning conflict over the economy between the mainstream left and right has thus opened a highway for the radical right to attract the working-class vote over cultural issues (Mudde 2007). All the more so as the traditional left further alienated its blue-collar basis by following the new left and adopting increasingly libertarian cultural positions. In this context, the radical right has made belonging to the national community an attractive identity. By upholding national sovereignty against disappearing borders and defending local traditions against multiculturalism, it has become a powerful contender for the working-class vote (Bornschier 2010; De Lange 2007; Oesch 2008a). Competitors not only include the left, but also non-voting. Traditionally, electoral turnout has been lower among vulnerable groups such as the working class (Oesch 2006).

The radical right not only challenges the left over the working-class vote, but also the centre-right over its traditional stronghold of small business owners. Economically, these two classes form an uneasy alliance: the working class is pro-redistribution and small business owners are pro-business (Ivarsflaten 2005). However, they share similar preferences on cultural issues. The radical right's resistance to open borders and multiculturalism also strikes a chord with small business owners (Kriesi et al. 2008). While their economic preferences move them towards the centre-right, their cultural attitudes lead them to support the radical right.

Our model expects limited competition for the classes that are party preserves, and a twoway competition for the contested strongholds. In contrast, electoral competition is likely to be very open for two classes whose occupational location puts them close to the median voter: technical specialists and office clerks. The former require higher levels of education, earn above-average wages and are less vulnerable to technological change. Accordingly, they may be somewhat more market-liberal and culturally libertarian than clerks. Still, for these two classes, we do not expect any party pole to have a decisive advantage over the two others. 


\section{Hypotheses on class voting}

This overview allows us to summarise our hypotheses about the micro-foundations of the electoral competition in the tripolar political space. First, with respect to party preserves, we expect sociocultural professionals to disproportionately vote for the left, and to do so based on their cultural preferences (H1). Likewise, we expect managers to disproportionately vote for the centre-right, and to do so based on their economic preferences $(H 2)$.

Second, with respect to contested strongholds, we expect the working class, and notably production workers, to split their vote between the left (based on their economic preferences) and the radical right (based on their cultural preferences) (H3). Likewise, we expect small business owners to split their vote between the centre-right (based on their economic preferences) and the radical right (based on their cultural preferences) (H4).

Third, in a temporal perspective, we expect the electoral rise of the radical right to have no influence on the two party preserves - sociocultural professionals (and their vote for the left) and managers (and their vote for the centre-right) (H5) - but to go along with growing support in the two contested strongholds - production workers (at the cost of the left) and small business owners (at the cost of the centre-right) (H6).

\section{Definition of party poles, data and measures}

\section{Definition of party poles}

We define the three party poles on the basis of parties' ideology and limit our analysis to Western Europe. The attribution of most parties to either one of the three poles seems straightforward. The left includes the socialist, social democratic and labour parties, as well as green parties, communist parties and radical left parties. The centre-right includes the conservative, Christian democratic, centre and liberal parties. While there are a few parties whose attribution to either the left or centre-right is more controversial, they account for a small proportion of the electorate. ${ }^{3}$ We attribute those parties to the radical right that share an ideology of nativism, authoritarianism and populism (Mudde 2013: 3). This pole thus includes former traditional centre-right parties such as the Swiss People's Party and the Austrian Freedom Party (during its liberal period in the early 1980s), former anti-tax movements such as the Danish People's Party and the Norwegian Progress Party, extremeright parties such as the French National Front and Flemish Vlaams Belang as well as newcomers with a strong nationalist-populist profile such as the Dutch Freedom Party, the Finns Party and the Sweden Democrats. Table A1 in the Appendix shows the parties that we consider belonging to the Radical Right and their scores in all the national elections between 2000 and 2015 (see also the Online Appendix).

Our model of just three party poles may seem overly simplistic as it implies combining parties of the old and new left, on the one hand, and liberal-centrist and conservative parties, on the other. We respond to this concern by replicating our analysis with the largest single party within each pole: the social-democratic or labour party for the left and the conservative or Christian democratic party for the centre-right - except in Denmark with Venstre and Switzerland with the Radical-Liberals (see the Online Appendix for the largest party of each pole). 


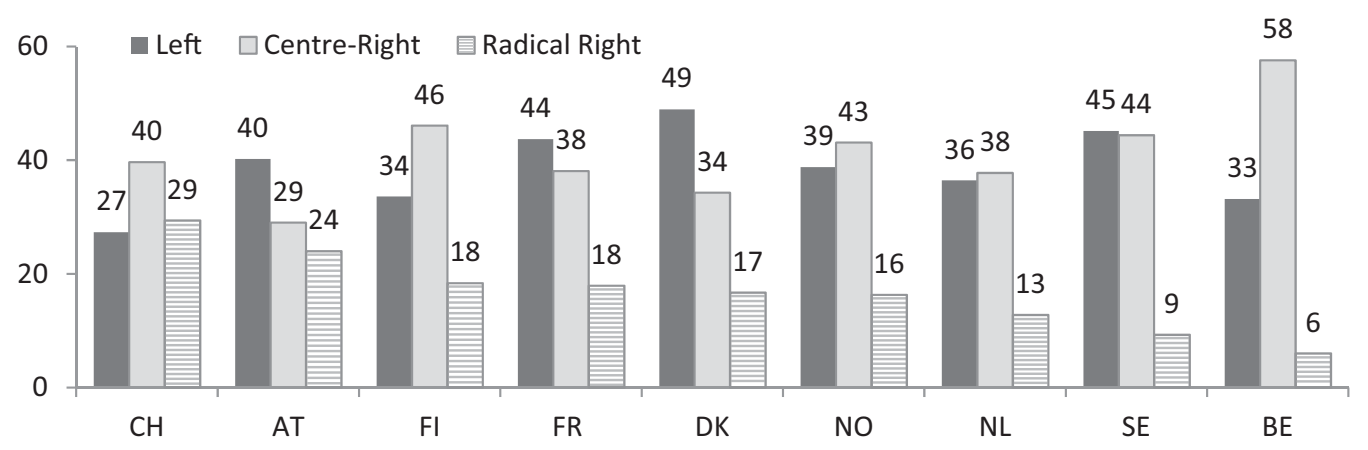

Figure 2. Electoral strength of the three poles 2010-2015 in Western Europe (in per cent).

Notes: Only includes countries with a radical right pole in at least one election over the entire period 20002015, see Table A1 in the Appendix. If there was more than one national election over the period 2010-2015, we calculated the average scores.

We consider parties to form a pole if they obtain at least 12 per cent of the votes in a national election over the period 2000-2015. This criterion was chosen for two reasons. First, if a radical right party reaches a threshold of 10-15 per cent, it acquires real electoral weight and makes the government formation by a mainstream left or right party bloc much harder, thereby leading to a tripolar political configuration. Second, this criterion allows us to analyse the electorate of the radical right with micro-data: A higher threshold of 15 or 20 per cent would exclude several elections and leave us with a small number of radical right voters.

\section{The size of the three poles}

Over the period under study, the 12 per cent mark is systematically surpassed by the poles of the left and centre-right. The formation of a tripolar political space therefore largely depends on the radical right's capacity to attract enough voters to constitute a third party pole. In the first group of countries, the radical right is either absent, insignificant, (still) too small to be considered a third pole or made its national breakthrough after 2015. This is the case for Germany, Ireland, Luxembourg, Portugal and Spain as well as the more ambiguous case of Italy (not taking into account the populist Five Star Movement).

The West European countries with a sizeable radical right pole can be divided into two groups. In the first group, the radical right was solidly established over the entire period between 2000 and 2015, and includes Austria, Denmark, France, Norway, Switzerland and, with more fluctuations, Belgium and the Netherlands. In the second group, the radical right has made its breakthrough more recently and only emerged as a third pole after 2010 . This applies to Finland and Sweden as well as to Greece and the United Kingdom - two countries not covered by our data and hence excluded from the analysis.

Figure 2 presents, for these countries, the electoral strength of the three poles, averaged over the most recent period from 2010 to 2015. We observe the clearest tripolar configuration of the party system in Austria and Switzerland where the radical right pole attracts a quarter of the electorate. In Denmark, Finland, France and Norway, the radical 
right pole receives between 15 and 20 per cent of the vote. In Belgium, the Netherlands and Sweden, the radical right barely obtains 12 per cent of votes and clearly constitutes a smaller pole than the left or the centre-right.

\section{Countries and data}

Our analysis of class voting is set at the individual level and based on data from the ESS and collected biennially since 2002 . We merge the seven available rounds between 2002 and 2014 into a single dataset. Our sample only comprises those countries and elections when all three poles - and notably the radical right - obtained at least 12 per cent of votes. Therefore, we include all seven rounds for Denmark, Norway and Switzerland, but one single round for Sweden (i.e., 2014, when the Sweden Democrats received 12.9 per cent of the national vote). The nine countries in our sample are Austria (4 rounds), Belgium (3), Denmark (7), Finland (2), France (5), Netherlands (2), Norway (7), Sweden (1) and Switzerland (7).

Our study focuses on electoral competition in the tripolar political space - and therefore only includes countries with such a configuration. However, we try to better understand class voting in the tripolar political space by using a temporal and spatial point of comparison. Temporally, we compare class voting in Finland and Sweden before and after the electoral breakthrough of the radical right. Spatially, we contrast class voting in the tripolar political space with the pattern found in countries that did not have a third party pole over the period under study: Germany, Ireland, Portugal and Spain. For these four countries, we merge all seven rounds of the ESS.

\section{Measures}

In the ESS, respondents are asked what party they voted for in the last national parliamentary election. This question provides us with the dependent variable: party choice grouped into three poles: left, centre-right, radical right. ${ }^{4}$ We correct for the underrepresentation of radical right voters in the ESS by constructing individual-level weights that adjust our data for the official score that each pole received in the national election corresponding to a given ESS round. We apply these weights, as well as the ESS design weights, to all our analyses. Not using these weights leads to the same conclusions (see the Online Appendix).

Our key independent variable is voters' class position - their location within the labour market - which we measure with a detailed class schema based on two dimensions (Oesch 2006). A first dimension distinguishes hierarchically between more or less advantageous employment relationships based on people's marketable skills, whereas as a second dimension discriminates horizontally between different work logics.

The combination of the two dimensions leads to the eight-class schema shown in Table A2 in the Appendix. This schema allows us to identify three classes belonging to the salaried middle class: (1) managers such as personnel managers, accountants and administrators; (2) technical specialists such as engineers, information technology specialists and technicians; and (3) sociocultural professionals and semi-professionals such as doctors, teachers and social workers. Two other classes form the working class: (4) production 
workers such as mechanics, assemblers and carpenters; and (5) service workers such as waiters, shop assistants and nursing aides. Another class is in the twilight zone between the middle and working class: (6) clerks such as secretaries, postal clerks and receptionists. Finally, we distinguish two classes of the self-employed: (7) large employers and liberal professionals such as self-employed lawyers and dentists; and (8) small business owners such as shop owners, independent artisans and farmers.

Respondents to the ESS are allocated to one of these eight classes based on their current or, if missing, past job. We thus also attribute a class location to the unemployed, retired or economically inactive based on their previous occupation. Our class measure uses three sets of information: employment status (separating employers and the self-employed from employees), the number of employees (separating large employers with 9+ employees from small business owners with 0-8 employees) and, most importantly, detailed occupational information (based on the International Standard Classification of Occupations [ISCO 4digit]). 5

Alongside the class variable, we construct two indicators for citizens' preferences on the economic-distributive and cultural-identitarian axes. For the economic axis, we use the only item about economic preferences that has been asked in all seven ESS rounds 'government should reduce differences in income levels' ${ }^{6}$ - answered on an ordinal fivepoint scale (from 'strongly agree' to 'strongly disagree'), which we standardized between 0 and 1. For the cultural axis, we use three items regarding immigration ('cultural life is undermined or enriched by immigrants'), the European Union ('European unification should go further or has gone too far') and cultural liberalism ('gays are free to live as they wish'). ${ }^{7}$ Again, we standardise the responses (given on an eleven-point scale or five-point scale for the item on cultural liberalism) between 0 and 1 and calculate each voter's position on the cultural axis as his or her average value on these three items. $^{8}$

\section{Class voting for the left, centre-right and radical right}

The class basis of the three party poles is visible in Figure 3, which shows for each class the difference from the party pole's mean score in percentage points. Horizontal bars to the left thus imply below-average electoral support and bars to the right above-average support. Our data confirm the presence of two party preserves. The first preserve comprises sociocultural professionals who lend disproportionate support to the left: 54 per cent of this growing class voted for the left, as compared to 35 per cent for the centre-right and a mere 7 per cent for the radical right. If it were only for sociocultural professionals, the radical right would be condemned to an irrelevant minority status.

The second party preserve comprises capital owners and their agents: large employers and self-employed professionals, small business owners and managers. The centre-right is particularly successful among large employers and self-employed professionals among whom it obtains 56 per cent of all votes - twice as much as the left and four times as much as the radical right. The centre-right also holds greatest appeal among small business owners. The competition for this class is clearly in favour of the centre-right (53 per cent of all votes), although small business owners also lend disproportionate support to the radical right (23 per cent), preferring it over the left (21 per cent). 

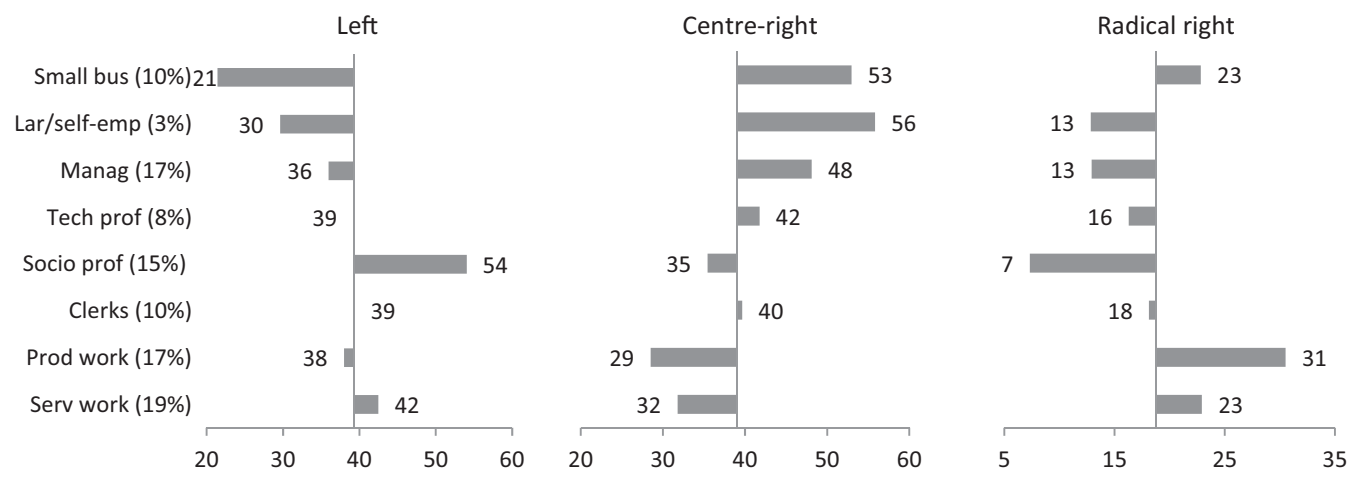

Figure 3. Electoral support for the three poles by social class (in per cent).

Legend for classes: Serv work $=$ Service workers; Prod work $=$ Production workers; Clerks $=$ Clerks; Socio prof $=$ Sociocultural professionals; Tech prof $=$ Technical professionals; Manag $=$ Managers; Lar $/$ self$\mathrm{emp}=$ Large employers and self-employed professionals, Small bus $=$ Small business owners. The percentages in parentheses next to the classes show the size of each class in the electorate.

Note: The y-axis cuts the $\mathrm{x}$-axis at a party's overall electoral score (the mean score over all the classes, which was 39.3 per cent for the left, 39.0 per cent for the centre-right and 18.8 per cent for the radical right).

Source: ESS, $N=43,742$. Data weighted.

Our hypothesis of a contested stronghold applies better to the working class - production and service workers - than to small business owners. While the centre-right makes its lowest score among production and service workers, the radical right is most successful among these same two classes with 31 and 23 per cent of their votes, respectively. Were it only for production workers, the radical right would be much stronger with almost a third of the electorate. It thus clearly challenges the left over the working class.

The different class profiles of our three party poles emerge more clearly when we adopt a compositional perspective and disaggregate each pole's electorate according to class (see Figure A1 in the Appendix). The radical right strongly depends on the workingclass vote. Half of its voters are either production or service workers, as compared to a third of the left's electorate and a quarter of the centre-right's electorate. The left compensates its waning stronghold among working-class voters with success among sociocultural professionals. They make up 21 per cent of its electorate, as compared to only 6 per cent among radical right voters. The centre-right in turn relies less on the working class and sociocultural professionals, but draws its strength from large employers and liberal professionals, managers and small business owners. Together, these entrepreneurial classes constitute almost 40 per cent of its electorate, as compared to 24 per cent of the left and 26 per cent of the radical right. Contrary to our expectation, small business owners do not weigh heavily within the radical right's electorate. They make up only 12 per cent - and therefore less than in the electorate of the centre-right (14 per cent), but more than in that of the left ( 6 per cent).

If we replicate the analysis of class voting by distinguishing the parties within the poles (notably the social democrats from the new left and the conservatives from the liberalcentrist right), results remain unchanged for the centre-right and the radical right, but show two nuances for the left (see the Online Appendix). The leftist success among sociocultural professionals is not due to social democratic parties, but to the fact that the new left (such 
as the green party) is exceptionally popular among this class of professionals working in health care, education, social welfare, the media and arts. Second, when separating social democrats from voters of the new left, we observe that the former still obtain their highest score among production and service workers. This finding is less marked when looking at the left as a party family because the new left does not fare well within the working class.

The working class is also known for showing particularly high rates of electoral abstention. Indeed, if we look at non-voting as a potential outcome, we find it to be highest among production and service workers, with 23 per cent declaring that they did not participate in the last election. In contrast, non-voting is lowest among large employers, managers and sociocultural professionals with only 11 per cent abstention. The competition over the working-class vote could thus also be described as three-way: between the left, the radical right and abstention (see the Online Appendix).

\section{A comparison of class voting in time and space}

Our argument about class voting in the tripolar political space has a temporal dimension: We expect the realignment between classes and party poles to be triggered by the rise of the radical right. Finland and Sweden allow us to test this argument as our data cover both an election without a tripolar configuration (when the radical right was still irrelevant) and with a tripolar configuration (when the radical right made its breakthrough). In Finland, the radical right increased its voting share fourfold from 4 to 19 per cent between the elections of 2007 and 2011. In Sweden, it doubled its share from 6 to 13 per cent between the elections of 2010 and 2014.

We calculate for each class the difference in party support before and after the emergence of a tripolar political space (see Figure A2 in the Appendix). In both countries, the radical right made its largest gains among production workers $(+26$ percentage points in Finland, +18 in Sweden), followed by small employers ( +18 points in Finland, +11 in Sweden). For the left, the rise of the radical right meant heavy electoral losses among production workers ( -19 points in Finland, -8 in Sweden) and moderate losses among service workers and clerks. While the radical right strongly challenged the left over the working-class vote, it had no impact on support for the left among sociocultural professionals. This support remained (almost) stable in Finland and increased strongly in Sweden (by 15 points). With the emergence of a tripolar configuration, the centre-right lost out most clearly among small business owners in Finland ( -15 points) and large employers and self-employed professionals in Sweden ( -23 points).

Another possibility is to compare class voting across countries and to examine party support between political systems with and without a tripolar configuration. We do so by calculating for each class the difference in party support for the left and the centre-right between countries where the political space was tripolar over the entire period 2000-2015 (Denmark, Norway, Switzerland) and countries where it was not tripolar over the same period (Germany, Ireland, Portugal and Spain) (see Figure A3 in the Appendix as well as the Online Appendix).

Overall, the left is 4 percentage points weaker in countries with a tripolar configuration. This lower electoral score is primarily due to the left being less successful among production workers, technical professionals and small business owners if it has to compete with 


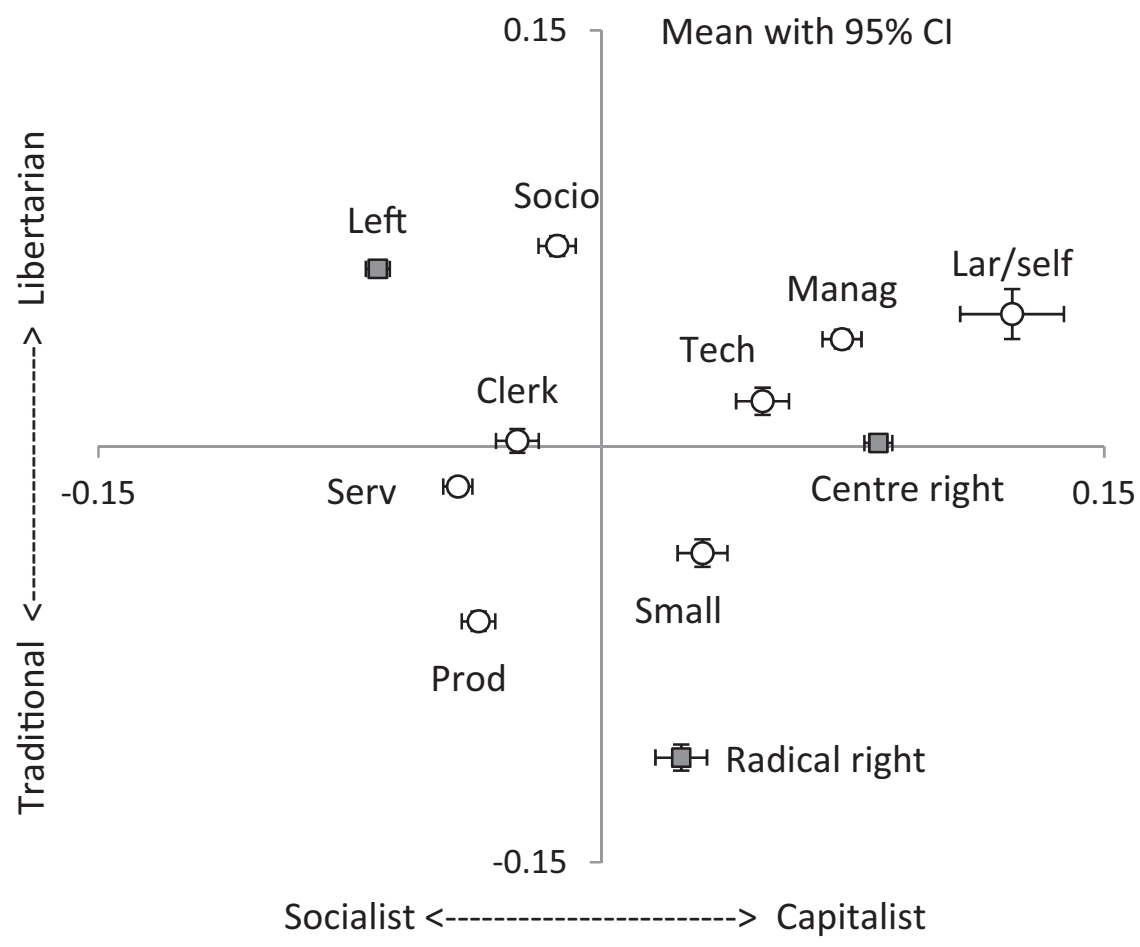

Figure 4. Location of voters in a two-dimensional space, by class and party pole. Note: For legend for classes, see Figure 3.

Source: ESS 2002-2014. Data weighted.

the radical right. By contrast, it is more successful among sociocultural professionals in countries with a third pole constituted by the radical right. The centre-right pole, in turn, is 9 percentage points weaker in countries with a tripolar configuration. While the centre-right loses more than the left overall, there is less variation across social classes. Still, its losses tend to be more concentrated among service workers, production workers and small business owners than among managers and large employers.

The emergence of a tripolar political space thus seems to affect specific constituencies of the left, depressing the support among production workers, but fostering the votes of sociocultural professionals. For the centre-right, the losses are distributed more homogeneously and affect all the constituencies, with the possible exception of its business stronghold of managers and employers.

\section{The economic and cultural attitudes linking classes with party poles}

We expect different class positions to go along with different sets of attitudes - and these attitudes should pick up the class effect and translate it into party choice. The questions asked in the ESS, outlined above, allow us to plot voters' preferences on the economic and cultural axes into the two-dimensional political space shown in Figure 4. Although we aggregate voters' preferences at the level of both classes and party poles, our analysis only 
relates to the electoral demand-side: The location of a given party pole thus reflects the mean positions of their voters on economic and cultural issues.

At the level of party poles, we observe the triangular configuration found by other scholars (e.g., Kriesi et al. 2008; Van Der Brug \& Van Spanje 2009). Voters of the centre-right are close to the median voter in terms of cultural preferences, but hold distinctly marketliberal economic attitudes. Voters of the radical right are economically more centrist than those of the centre-right, but take a more right-wing stance over cultural issues and cluster at the bottom end of the cultural-preference axis. Voters of the left stand out in terms of both their socialist attitudes on the economic axis and their libertarian attitudes on the cultural axis. Economically, they are at greatest variance from the voters of the centre-right. Culturally, they differ most from the voters of the radical right.

At the level of classes, sociocultural professionals are particularly libertarian. Although they also take a more leftist stance over economic issues, what sets them apart is their cultural libertarianism. The opposite - traditional - end of the cultural axis is occupied by small business owners and, above all, production workers. While these two classes share similar cultural attitudes, they diverge on economic preferences. Small business owners are more market-liberal, and in this respect more similar to the electorate of the centre-right, whereas production workers hold more leftist economic attitudes.

These results on attitudes suggest that the three party poles compete most fiercely over three class segments. First, the left and the radical right compete for the working class. Depending on whether economic or cultural issues are more salient, production and service workers either choose the left or the radical right. Second, the left and the centreright compete for the salaried middle class (managers and technical specialists), and this conflict mainly concerns the economic dimension. Third, the centre-right and the radical right compete for small business owners, and this conflict relates to the cultural dimension.

To what extent do economic and cultural preferences account for the class differences in party choice? We examine this question by estimating multinomial regressions on the determinants of voting for one of the three party poles (see Table 1). Resorting to a multivariate model also allows us to test whether the link between classes and party poles holds once we control for other determinants of voting such as gender, age, education, the place of residence (city, town, suburb, village) as well as for country and year (ESS round). We present the results as marginal effects and choose clerks as the reference category because they are close to the median voter.

Model M1 presents the class effect on party choice after controlling for all the other sociodemographic characteristics. The results provide the same conclusions as did the descriptive evidence shown above. The radical right draws its largest support from production workers and small business owners, but is least successful among sociocultural professionals and managers. The left is most successful among production workers, service workers and, above all, sociocultural professionals, but holds least appeal among managers, large employers and small business owners. The centre-right presents the mirror image of the left, losing out among working-class voters and sociocultural professionals, but receiving strong support from small business owners, large employers and managers. These marginal effects are not only statistically significant, but often exceed 10 percentage points and thus indicate that the class differences in voting for the three party poles are substantial. If we run a separate regression for each of our nine countries, we basically obtain the same 


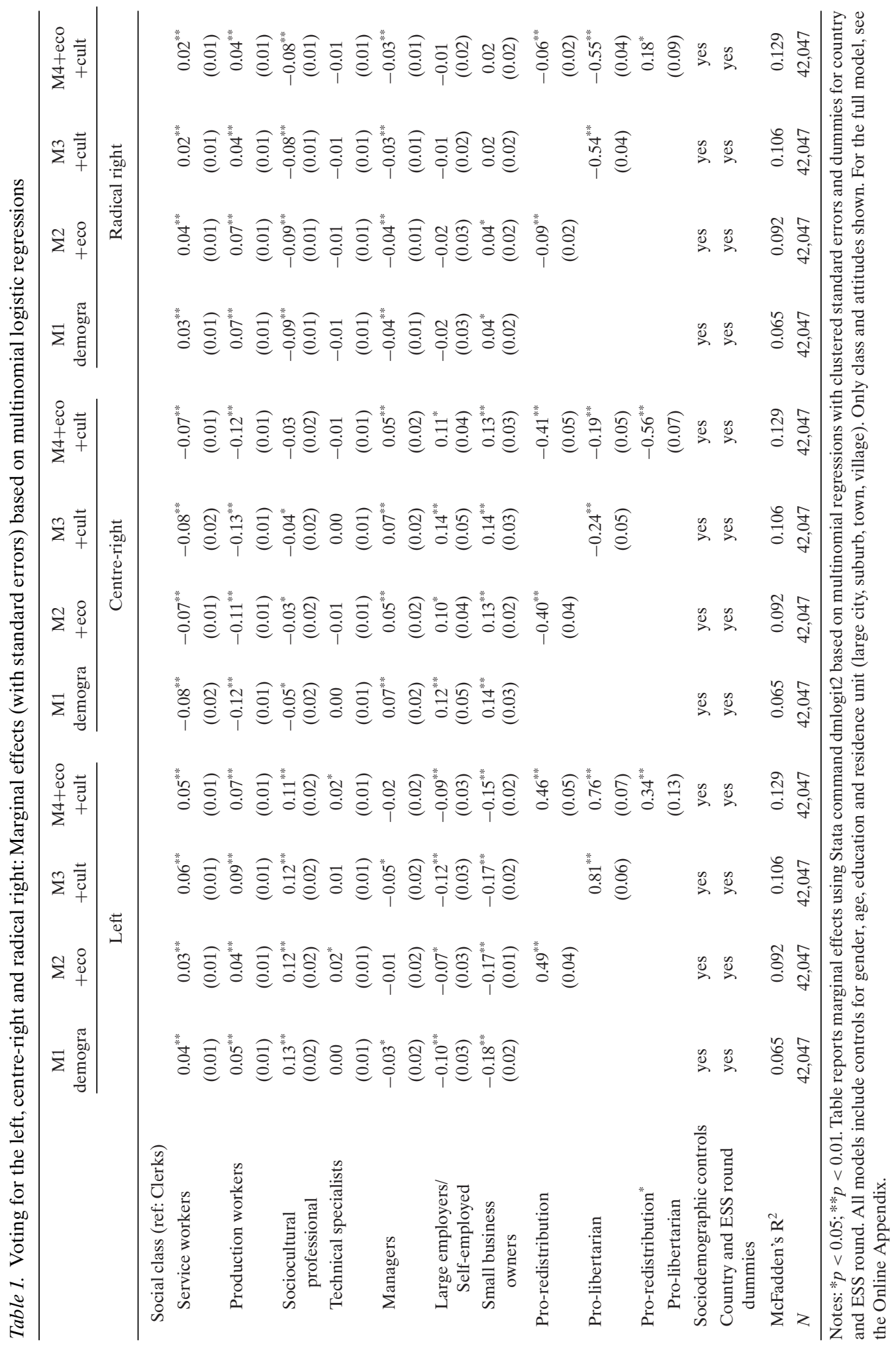


configuration between classes and parties. Likewise, conclusions remain unchanged if we solely focus on the largest party within each pole (see the Online Appendix).

The introduction of economic attitudes into the model M2 partly explains why large employers and managers dislike the left and endorse the centre-right - the effects become smaller for these classes once we account for differences in their economic attitudes. Economic attitudes also explain, albeit marginally, why production and service workers disproportionately support the left and avoid the centre-right. However, they contribute nothing to the explanation of why production and service workers vote for the radical right. If we hold economic attitudes constant, the class effect becomes even larger for service workers. The radical right gains the support of the working class not thanks to its free-market programme, but despite it (Ivarsflaten 2005; Oesch 2008a).

Introducing cultural attitudes in model M3 changes nothing for the voters of the centreright. Clearly, it is voters' economic preferences - and not their cultural attitudes - that explain the differential support among classes for the centre-right. In contrast, conflict on cultural attitudes is decisive for the radical right. The class effect of production and service workers is almost halved if we hold cultural preferences constant - and becomes insignificant in the case of small business owners. For the left, cultural attitudes have less bearing on class voting than do economic attitudes. If we keep cultural attitudes constant, production and service workers become more likely - and managers less likely - to vote for the left. In other words, the working class supports the left despite its culturally libertarian programme (see also Lefkofridi et al. 2014).

When introducing both economic and cultural preferences in model M4, we find that attitudes pick up the class effect only to a small extent. However, preferences go in the expected direction. Both the economic and cultural dimension matter for voters of the left. In contrast, voters of the centre-right primarily vary from other voters by holding more economically liberal attitudes, whereas voters of the radical right primarily vary by holding more culturally traditional attitudes. The interaction effects between the two attitudinal scales are positive for the left and negative for the centre-right. This suggests that the combination of attitudes favourable to economic redistribution and cultural libertarianism further stimulates voting for the left, whereas the opposite combination strengthens support for the centre-right.

In a last analysis, we illustrate how attitudes affect party choice by plotting the predicted probabilities of a mid-aged male production worker to vote for either one of the three poles, depending on his economic and cultural attitudes. If we set cultural attitudes at the average value and only vary economic attitudes (Figure 5, left-hand panel), we find that the left dominates among those production workers who strongly favour redistribution, whereas the centre-right makes important inroads among those production workers who strongly oppose redistribution. Voting for the radical right varies little and remains at a comparatively low level. However, if economic attitudes are held constant at the average value and only cultural attitudes vary, we find that the radical right receives massive support among production workers with traditional attitudes, whereas the left dominates among production workers with libertarian attitudes (Figure 5, right-hand panel). It is now voting for the centre-right that varies little and remains at a low level.

These analyses clearly show that the radical right successfully competes for the workingclass vote (as for the vote of small business owners) thanks to cultural conflict, whereas 
Economic attitudes

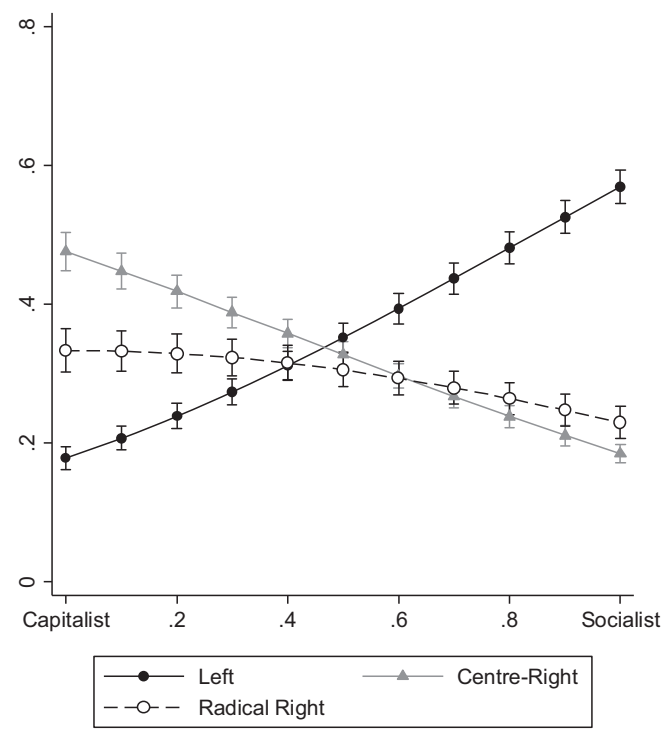

Cultural attitudes

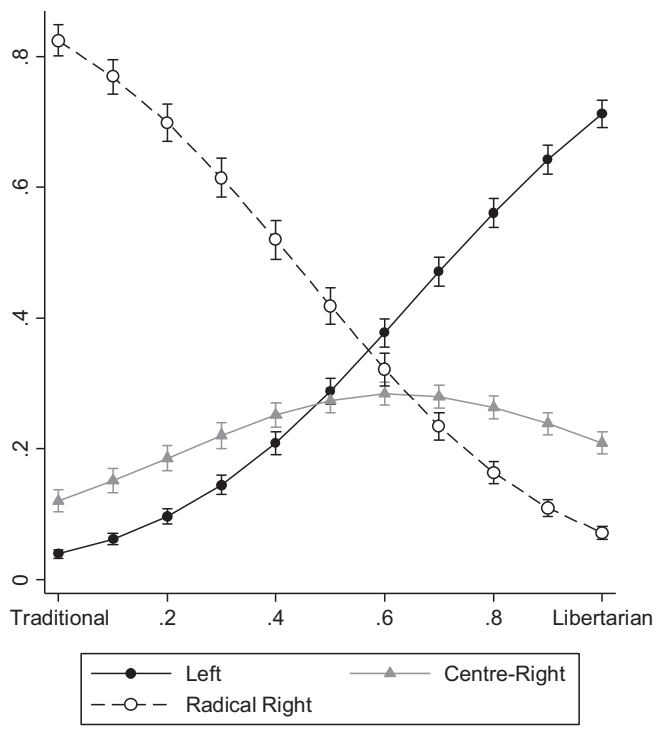

Figure 5. Voting for one of the three party poles (in per cent): Predicted probabilities for a mid-aged male production worker, depending on his economic and cultural attitudes.

Notes: Predicted probabilities based on model 4, Table 1. Vertical bars show 95 per cent confidence intervals. Probabilities are calculated for a production worker, male, 35-44 years, upper-secondary education, living in a small city, with cultural attitudes held at their mean value (left-hand panel) and economic values held at their mean value (right-hand panel).

the centre-right and, to a lesser extent, the left mobilise along economic conflict lines. This further suggests that the old working-class vote for the mainstream centre-right parties is different from the new working-class vote for the radical right. Anti-redistributive economic attitudes drive the former, whereas traditional cultural attitudes explain the latter.

\section{Discussion and conclusion}

The rise of the radical right fundamentally changes the face of electoral competition in Western Europe as we knew it over much of the postwar period. Bipolar competition is becoming tripolar, as the two traditional party poles of the left and the centre-right are challenged by a third pole - the radical right - in a growing number of countries. The expectation that radical right parties would constitute ephemeral protest movements did not materialise. Between 2000 and 2015, the radical right has secured more than 12 per cent of the electorate in over ten Western European countries and in over twenty national elections.

Our objective was to examine how electoral competition between the three party poles plays out at the micro level of different social classes. We presented a model of class voting that distinguishes three types of relationships between classes and parties: some classes are one party pole's preserve, other classes are the contested stronghold of two party poles, and over still other classes there is an open competition between three party poles. 
Our analysis confirms the hypotheses about the party poles' preserves. While the left receives disproportionate support among sociocultural professionals, the centre-right dominates among large employers, self-employed professionals and managers. Sociocultural professionals' attachment to the (new) left owes as much to cultural as to economic preferences. In contrast, the endorsement of the centre-right by employers and their agents is primarily motivated by economic attitudes. With electoral shares of 50 per cent, one can rightfully talk about party preserves in the case of sociocultural professionals on the left, large employers and managers on the right.

If the electoral domination of the old and new middle classes seems largely out of reach for the radical right, the one notable exception are small business owners - a class whom Marxists named, somewhat derogatorily, the 'petite bourgeoisie'. While the radical right made larger inroads into the electorate of small business owners than into any of the other middleclass segments, their electoral relevance for the radical right should not be overestimated. The centre-right obtains significantly larger voting shares among small business owners who, moreover, are of minor demographic importance in Western Europe where they account for no more than 10 per cent of the electorate.

Our hypothesis of a contested stronghold applies better to the working class. The radical right receives its highest score among production and service workers, and thus provides a serious challenge to the left over its traditional working-class stronghold. In terms of economic attitudes, production and service workers are close to the left and lend significantly stronger support to the left than do clerks, technical specialists or managers. However, their cultural preferences are in closer accordance with the radical right, explaining why the electorate of the radical right has the strongest working-class bias of the three party poles. Our analysis thus adds comparative evidence for the increasing proletarianisation of the radical right's electorate in Western Europe (see also Bornschier 2010; De Lange 2007).

The contested strongholds attest to the co-existence of old and new patterns of class voting. Old patterns, in which party dominance over one class has weakened without disappearing, tend to be structured along the economic axis of conflict. Examples are production workers' support for the left and small business owners' endorsement of the centre-right. In contrast, the emergence of new patterns is due to the rise of the new left and the radical right - and is mostly structured along the cultural axis of conflict (Mudde 2007). Examples are the affinity of sociocultural professionals for the left as well as the support among production workers and small business owners for the radical right.

In the last decades, it has become common in political science to study party competition independently from the social divisions that underlie European electorates. The process of de-alignment between social classes and political parties has been interpreted as closing the historical chapter of class voting (e.g., Franklin et al. 2009). Our findings suggest that, on the contrary, party competition continues to be firmly rooted in the social structure and that we observe the realignment between classes and parties. Each party pole has a distinctive social basis which is the joint outcome of persisting old divisions and the development of new contrasts between classes. Moreover, a clearly defined social basis is not the prerogative of the smaller pole of the radical right, but also applies to the left and centre-right. 
At the same time, political parties cannot solely rely on the mobilisation of their party preserves to reach electoral majorities. Given the small size of the different classes, parties only obtain stable majorities if they succeed in creating new coalitions of voters. Our analysis suggests that with the shrinking of the two traditional party poles and the rise of the radical right, the forging of solid coalitions will become more difficult in the new tripolar political space. The tripolar electoral competition may thus also inaugurate a new period of increased government instability in Western Europe.

\section{Acknowledgements}

We gratefully acknowledge the comments of seminar participants at the European University Institute in Florence, Science Po Paris and Switzerland's Annual Conference of Political Science at the University of St Gallen. Particular helpful were the comments by Reto Bürgisser, Hanspeter Kriesi, Alexander Trechsel and the two anonymous reviewers as well as the language revision by Patrick McDonald and Alyson Price. This research benefitted from the financial support of the University of Lausanne's Faculty of Social and Political Science.

\section{Appendix}

Table A1. Detailed score of parties included in the radical right pole in elections 2000-2015

\begin{tabular}{|c|c|c|c|c|c|c|c|c|c|c|c|}
\hline & \multirow[b]{2}{*}{ Election years } & \multirow[b]{2}{*}{ Party } & \multirow[b]{2}{*}{ Party name } & \multicolumn{8}{|c|}{ Elections } \\
\hline & & & & E1 & E2 & E3 & $\mathrm{E} 4$ & E5 & E6 & E7 & E8 \\
\hline \multirow[t]{3}{*}{ AT } & $\begin{array}{l}2002,2006 \\
2008,2013\end{array}$ & FPÖ & $\begin{array}{l}\text { Freiheitliche Partei } \\
\text { Österreichs }\end{array}$ & 10 & 11 & 17.5 & 20.5 & & & & \\
\hline & & BZÖ & Bündnis Zukunft Österreich & - & 4.1 & 10.7 & 3.5 & & & & \\
\hline & & Total & & 10 & 15.1 & 28.2 & 24 & & & & \\
\hline \multirow[t]{3}{*}{$\mathrm{BE}$} & 2003,2007 & VB & Vlaams Belang & 11.7 & 12 & 7.8 & 3.7 & & & & \\
\hline & 2010,2014 & FN & Front National & 2 & 2 & 0.5 & - & & & & \\
\hline & & Total & & 13.7 & 14 & 8.3 & 3.7 & & & & \\
\hline \multirow[t]{3}{*}{ DK } & 2001,2005 & $\mathrm{DF}$ & Dansk Folkeparti & 12 & 13.3 & 13.9 & 12.3 & 21.1 & & & \\
\hline & 2007,2011 & FrP & Fremskridtspartiet & 0.6 & & & & & & & \\
\hline & 2015 & Total & & 12.6 & 13.3 & 13.9 & 12.3 & 21.1 & & & \\
\hline \multirow[t]{2}{*}{ FI } & 2003,2007 & PS & Perussuomalaiset & 1.6 & 4.1 & 19.1 & 17.6 & & & & \\
\hline & 2011,2015 & & & & & & & & & & \\
\hline \multirow[t]{3}{*}{ FR } & 2002,2007, & FN & Front National & 16.9 & 10.4 & 17.9 & & & & & \\
\hline & 2012 & MNR & $\begin{array}{l}\text { Mouvement national } \\
\text { républicain }\end{array}$ & 2.3 & - & - & & & & & \\
\hline & & Total & & 19.2 & 10.4 & 17.9 & & & & & \\
\hline \multirow[t]{4}{*}{$\mathrm{DE}$} & 2002,2005 & REP & Die Republikaner & 0.6 & 0.6 & 0.4 & 0.2 & & & & \\
\hline & 2009,2013 & NPD & $\begin{array}{l}\text { Nationaldemokratische } \\
\text { Partei Deutschland }\end{array}$ & 0.4 & 1.6 & 1.5 & 1.3 & & & & \\
\hline & & AfD & Alternative für Deutschland & - & - & - & 4.7 & & & & \\
\hline & & Total & & 1 & 2.2 & 1.9 & 6.2 & & & & \\
\hline
\end{tabular}


Table A1. Continued

\begin{tabular}{|c|c|c|c|c|c|c|c|c|c|c|c|}
\hline & \multirow[b]{2}{*}{ Election years } & \multirow[b]{2}{*}{ Party } & \multirow[b]{2}{*}{ Party name } & \multicolumn{8}{|c|}{ Elections } \\
\hline & & & & E1 & E2 & E3 & $\mathrm{E} 4$ & E5 & E6 & E7 & E8 \\
\hline \multirow[t]{4}{*}{ GR } & 2000,2004 & LAOS & $\begin{array}{l}\text { Laikós Orthódoxos } \\
\text { Synagermós }\end{array}$ & - & 2.2 & 3.8 & 5.6 & 2.9 & 1.6 & 1 & - \\
\hline & 2007,2009 & ANEL & Anexartitoi Ellines & - & - & - & - & 10.6 & 7.5 & 4.8 & 3.7 \\
\hline & $2012 \mathrm{a}+\mathrm{b}$ & GD & Chrysi Avgi & - & - & - & 0.3 & 7 & 6.9 & 6.3 & 7 \\
\hline & $2015 a+b$ & Total & & 0 & 2.2 & 3.8 & 5.9 & 20.5 & 16 & 12.1 & 10.7 \\
\hline IT & 2001,2006 & $\mathrm{LN}$ & Lega Nord & 3.9 & 4.6 & 8.3 & 4.1 & & & & \\
\hline & 2008,2013 & & & & & & & & & & \\
\hline LU & $\begin{array}{l}2003,2009 \\
2013\end{array}$ & $\mathrm{ADR}$ & $\begin{array}{l}\text { Alternativ Demokratesch } \\
\text { Reformpartei }\end{array}$ & 10 & 8.1 & 6.8 & & & & & \\
\hline \multirow[t]{3}{*}{ NL } & 2002,2003 & PVV & Partij Voor de Vrijheid & - & - & 5.9 & 15.4 & 10.1 & & & \\
\hline & 2006,2010 & LPF & Lijst Pim Fortuyn & 17 & 5.7 & 0.2 & - & - & & & \\
\hline & 2012 & Total & & 17 & 5.7 & 6.1 & 15.4 & 10.1 & & & \\
\hline NO & $\begin{array}{l}2001,2005 \\
2009,2013\end{array}$ & FrP & Fremskrittspartiet & 14.6 & 22.1 & 22.9 & 16.3 & & & & \\
\hline PT & $\begin{array}{l}2002,2005 \\
2009,2011, \\
2015\end{array}$ & PNR & Partido Nacional Renovador & 0.1 & 0.2 & 0.2 & 0.3 & 0.5 & & & \\
\hline \multirow[t]{3}{*}{ ES } & 2000,2002 , & E-2000 & España 2000 & - & - & - & 0 & 0 & - & & \\
\hline & 2004,2008 & $\mathrm{DN}$ & Democracia Nacional & 0 & - & 0.1 & 0 & 0 & 0 & & \\
\hline & 2011,2015 & Total & & 0 & 0 & 0.1 & 0 & 0 & 0 & & \\
\hline SE & $\begin{array}{l}2002,2006, \\
2010,2014\end{array}$ & SD & Sverigedemokraterna & 1.4 & 2.9 & 5.7 & 12.9 & & & & \\
\hline \multirow[t]{6}{*}{$\mathrm{CH}$} & 2003,2007 , & SVP & Schweizerische Volkspartei & 26.7 & 28.9 & 26.6 & 29.4 & & & & \\
\hline & 2011,2015 & Lega & Lega dei Ticinesi & 0.3 & 0.6 & 0.8 & 1 & & & & \\
\hline & & MCG & $\begin{array}{l}\text { Mouvement citoyen } \\
\text { genevois }\end{array}$ & - & 0.1 & 0.4 & 0.3 & & & & \\
\hline & & SD & Schweizer Demokraten & 1 & 0.5 & 0.2 & 0.1 & & & & \\
\hline & & FPS & Freiheits-Partei der Schweiz & 0.2 & 0.1 & - & - & & & & \\
\hline & & Total & & 28.2 & 30.2 & 28 & 30.8 & & & & \\
\hline \multirow[t]{5}{*}{ UK } & 2001,2005 , & UKIP & UK Independance Party & 1.5 & 2.2 & 3.1 & 12.6 & & & & \\
\hline & 2010,2015 & $\mathrm{BNP}$ & British National Party & 0.2 & 0.7 & 1.9 & 0 & & & & \\
\hline & & NF & National Front & 0 & 0 & 0 & 0 & & & & \\
\hline & & DUP & Democratic Unionist Party & 0.7 & 0.9 & 0.6 & 0.6 & & & & \\
\hline & & Total & & 2.4 & 3.8 & 5.6 & 13.2 & & & & \\
\hline
\end{tabular}

Note: The score is 0 when a party reaches less than 0.1 per cent of the vote. 
Table A2. The eight-class schema, with three typical occupations in each class

\begin{tabular}{|c|c|c|c|}
\hline $\begin{array}{l}\text { Interpersonal service } \\
\text { logic }\end{array}$ & Technical work logic & $\begin{array}{l}\text { Organisational } \\
\text { work logic }\end{array}$ & Independent work logic \\
\hline $\begin{array}{l}\text { Sociocultural (semi-) } \\
\text { professionals }\end{array}$ & $\begin{array}{l}\text { Technical (semi-) } \\
\text { professionals }\end{array}$ & $\begin{array}{l}\text { (Associate) } \\
\text { managers }\end{array}$ & $\begin{array}{c}\text { Liberal professionals and } \\
\text { large employers }\end{array}$ \\
\hline Medical doctors & Engineers & Administrators & Entrepreneurs \\
\hline Teachers & Architects & Consultants & Lawyers \\
\hline Social workers & $\begin{array}{l}\text { Informational technology } \\
\text { specialists }\end{array}$ & Accountants & Dentists \\
\hline Service workers & Production workers & Office clerks & $\begin{array}{c}\text { Small business owners } \\
\text { and farmers }\end{array}$ \\
\hline Waiters & Mechanics & Secretaries & Shop owners \\
\hline Nursing aides & Carpenters & Receptionists & Independent artisans \\
\hline Shop assistants & Assemblers & Mail clerks & Farmers \\
\hline
\end{tabular}

Table A3. Parameter estimates of exploratory principal component analysis (PCA)

\begin{tabular}{lcc}
\hline & Component 1 & Component 2 \\
\hline Redistribution & $\mathbf{0 . 9 2}$ & 0.03 \\
Immigration & -0.02 & $\mathbf{0 . 6 5}$ \\
Europe & 0.23 & $\mathbf{0 . 6 0}$ \\
Cultural liberalism & -0.33 & $\mathbf{0 . 4 7}$ \\
Eigenvalue & 1.03 & 1.48 \\
$\mathrm{R}^{2}$ & $25.8 \%$ & $36.9 \%$ \\
\hline
\end{tabular}

Notes: Results of PCA with Varimax rotation. Factor loadings above 0.40 are in bold.

Source: ESS, country-rounds.

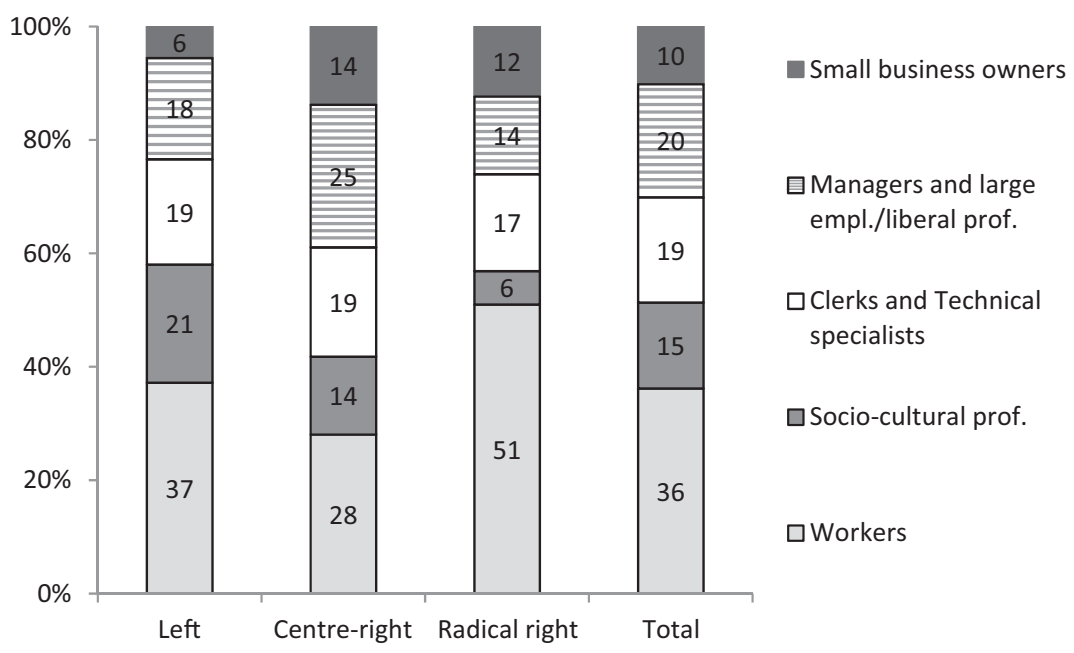

Figure A1. Class composition of the three poles' electorate.

Source: ESS, $N=43,742$. Data weighted. 

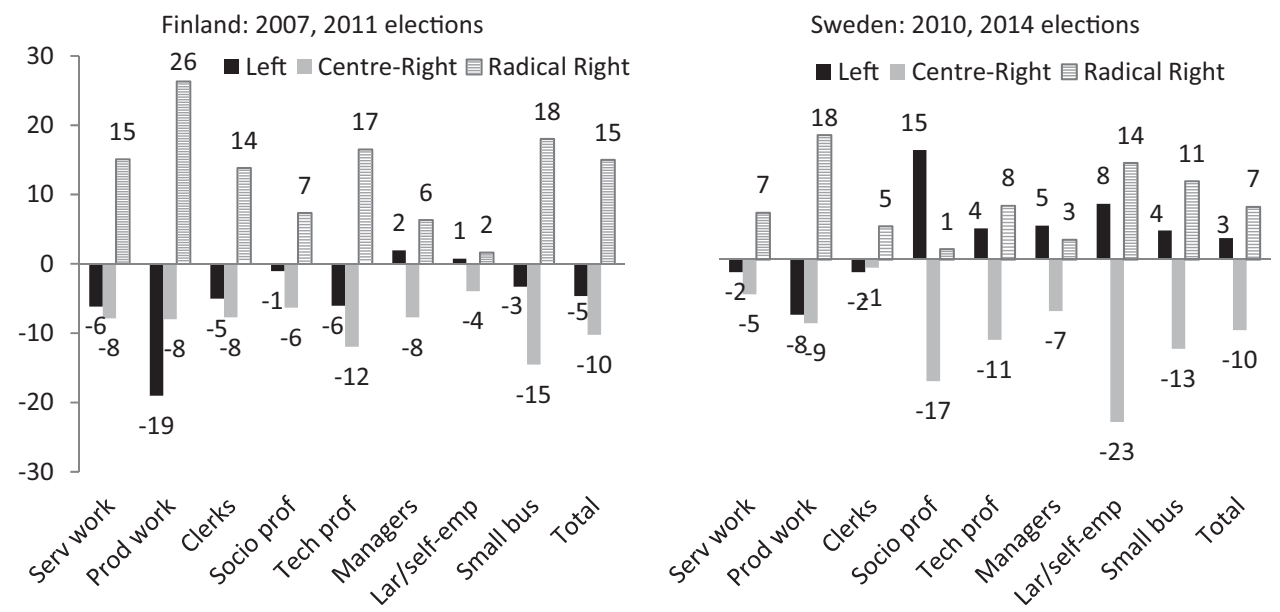

Figure A2. Difference in party support before and after the emergence of a tripolar configuration (in percentage points).

Notes: N Finland: $2007=2,527,2011=2,817$; N Sweden: $2010=2,628,2014=1,412$. For legend for classes, see Figure 3.

Sources: ESS 4-5 and ESS 6-7 in Finland; ESS 5-6 and ESS 7 in Sweden. Data weighted.

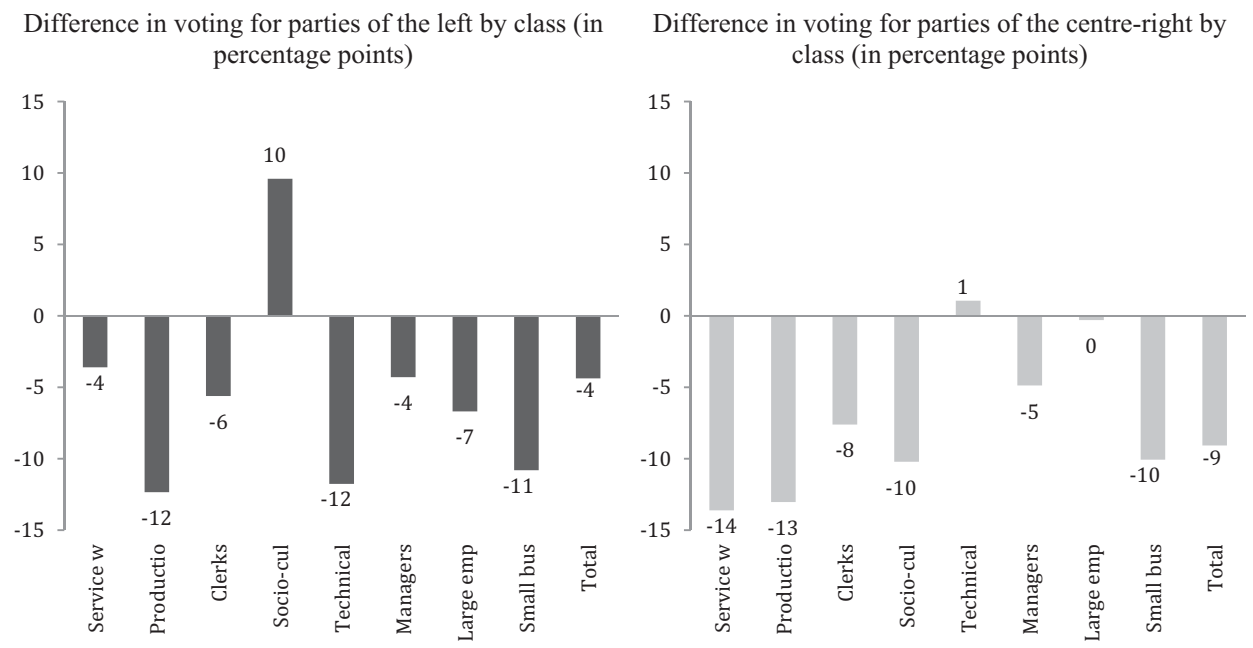

Figure A3. Party support by class in countries with a tripolar political space relative to countries without a tripolar political space.

How to read this figure: Support for the left among service workers is 4 percentage points lower in countries with a tripolar political space as compared to countries without a tripolar political space over the period covered by ESS 2002-2014. In contrast, support for the left is 10 percentage points higher among sociocultural professionals in a tripolar configuration as compared to a non-tripolar configuration.

Notes: Countries with a tripolar political space 2000-2015: CH, DK, NO $(\mathrm{N}=22,429)$. Countries without a tripolar political space 2000-2015: DE, ES, IR, PT $(\mathrm{N}=34,915)$. In the countries with a tripolar political space, the electoral score obtained by the left is 4 per cent lower and that by the centre-right is 9 per cent lower than in countries without a tripolar political space (i.e., without a large radical right party). 


\section{Supporting Information}

Additional Supporting Information may be found in the online version of this article at the publisher's web-site:

Figure W.1: Class composition of the electorate of the largest party of the Left, the CentreRight and the Radical Right as well as other parties of the Left and the Centre-Right

Figure W.2: Electoral support for the Left and Centre-Right in countries without a tripolar political space (in \%)

Figure W.3: Electoral support for the largest political parties within each pole by class (in \%)

Figure W.4: Electoral support for the three poles and non-voters by social class (in \%)

Figure W.5 without weights: Electoral support for the three poles by social class (in \%) without using individual-level weights that adjust the data for the official electoral score that each pole received

Figure W.5 with weights: Electoral support for the three poles by social class (in \%) - with individual-level weights that adjust the data for the official electoral score that each pole received

Figure W.6: Party choice in national elections with a tripolar political space - marginal effects for social class by country

Table W.1: political parties included in each of the three poles

Table W.2: Classification of the largest party in each pole

Table W.3: Strength of the Radical Right pole in legislative elections 2000-2015

Table W.4: Voting for the largest party of the Left, Centre-Right and Radical Right - average marginal effects (with S.E.) based on multinomial logistic regressions (full model)

Table W.5: Voting for the Left, Centre-Right and Radical Right - marginal effects (with S.E.) based on multinomial logistic regressions (full model)

\section{Notes}

1. www.europeansocialsurvey.org/

2. We focus on the electoral support a given party obtains in a given class relative to the overall electoral support. In absolute terms, the poles of the left and the centre-right remain more popular than the radical right in almost every class. A relative measure has the advantage of allowing us to compare a party pole's success across classes. However, we will provide results for both absolute and relative measures of class voting.

3. When attributing the social-liberal parties of Northern Europe to a party pole, we considered whether they were natural coalition partners of the left or centre-right. Therefore, we allocated the Dutch D66 and the Danish Radikale Venstre to the left because those two parties were more often in coalitions with the left than the centre-right. In contrast, Venstre in Norway participated more often in right-wing coalitions, so we classified it in the centre-right. A few parties were not attributed to any pole - notably some regionalist parties (e.g., SNP in Scotland), religious parties (e.g., SGP in the Netherlands, EDU in Switzerland), pirate parties, short-lived parties and smaller lists that are commonly classified under 'others' in official election results. For the detailed classification, see the Online Appendix.

4. As presidential elections are of greater relevance than parliamentary elections in France's semipresidential regime, we select the question about the candidate voted for in the last presidential election for France. 
5. For more detail on the class variable, see Oesch (2006: 270-272). The script used for the construction of this class schema can be downloaded in Stata or SPSS from: http://people.unil.ch/danieloesch/scripts/

6. As a robustness check, we use the ESS rounds 2002 and 2008 and measure the economic axis with an additional item. In 2002, this item is 'employees need strong trade unions to protect working conditions'; in 2008, 'jobs for everyone is government's responsibility'. The resulting configuration of voters' attitudes by class and parties looks very similar to the pattern observed with only one item.

7. The item on the EU is not available in rounds 1 and 5. In these two rounds, the cultural axis is based solely on the items relative to immigration and cultural liberalism.

8. A principal component analysis of the four items confirms that the question on differences in income levels loads heavily on a first component, whereas the three other items all load on a second component. Together, these two components explain 63 per cent of the variance in the four attitudinal variables (see Table A3 Parameter in the Appendix).

\section{References}

Afonso, A. (2015). Choosing whom to betray: Populist right-wing parties, welfare state reforms and the tradeoff between office and votes. European Political Science Review 7(2): 271-292.

Arndt, C. (2013). The electoral consequences of third way welfare state reforms. Amsterdam: Amsterdam University Press.

Bale, T. (2003). Cinderella and her ugly sisters: The mainstream and extreme right in Europe's bipolarising party systems. West European Politics 26(3): 67-90.

Bornschier, S. (2010). Cleavage politics and the populist right: The new cultural conflict in Western Europe. Philadelphia, PA: Temple University Press.

Bornschier, S. \& Kriesi, H. (2013). The populist right, the working class and the changing face of class politics. In J. Rydgren (ed.), Class politics and the radical right. New York: Routledge.

Bornschier, S. \& Lachat, R. (2009). The evolution of the French political space and party system. West European Politics 32(2): 360-383.

Cochrane, C. (2013). The asymmetrical structure of left/right disagreement. Party Politics 19(1): 104-121.

De Lange, S.L. (2007). A new winning formula? The programmatic appeal of the radical right. Party Politics 13(4): 411-435.

Evans, G. \& Tilley, J. (2012). How parties shape class politics: Explaining the decline of the class basis of party support. British Journal of Political Science 42(1): 137-161.

Franklin, M.N., Mackie, T.T. \& Valen, H. (2009). Electoral change: Responses to evolving social and attitudinal structures in Western countries. Colchester: ECPR Press.

Gingrich, J. \& Häusermann, S. (2015). The decline of the working-class vote, the reconfiguration of the welfare support coalition and consequences for the welfare state. Journal of European Social Policy 25(1): 50-75.

Grunberg, G. \& Schweisguth,E. (2003). La tripartition de l'espace politique. In P.Perrineau \& C. Ysmal (eds), Le vote de tous les refus: Les élections présidentielle et législatives de 2002. Paris: Presses de Sciences Po.

Hooghe, L., Marks, G. \& Wilson, C.J. (2002). Does left/right structure party positions on European integration? Comparative Political Studies 35(8): 965-989.

Ivarsflaten, E. (2005). The vulnerable populist right parties: No economic realignment fuelling their electoral success. European Journal of Political Research 44(3): 465-492.

Katz, R.S. \& Mair, P. (2009). The cartel party thesis: A restatement. Perspectives on Politics 7(4): 753-766.

Kitschelt, H. (1994). The transformation of European social democracy. Cambridge: Cambridge University Press.

Kitschelt, H. (2010). The comparative analysis of electoral and partisan politics: A comment on a special issue of West European Politics. West European Politics 33(3): 659-672.

Kitschelt,H.\& Rehm,P.(2014). Occupations as a site of political preference formation. Comparative Political Studies 47(12): 1670-1706.

Kriesi, H. (1998). The transformation of cleavage politics. European Journal of Political Research 33(2): 165185. 
Kriesi, H., Grande, E., Lachat, R., Dolezal, M., Bornschier, S., \& Frey, T. (2006). Globalization and the transformation of the national political space: Six European countries compared. European Journal of Political Research 45(6): 921-956.

Kriesi, H., Grande, E., Lachat, R., Dolezal, M., Bornschier, S., \& Frey, T. (2008). West European politics in the age of globalization. Cambridge: Cambridge University Press.

Kriesi, H., Hutter, S. \& Lorenzini, J. (2015). Restructuring the West European party space in the Great Recession: Continuity and change. Working Paper. Florence: European University Institute.

Lefkofridi, Z., Wagner, M. \& Willmann, J.E. (2014). Left-authoritarians and policy representation in Western Europe: Electoral choice across ideological dimensions. West European Politics 37(1): 65-90

Martin, P. (2013). Le déclin des partis de gouvernement en Europe. Commentaire 143(3): 542-554.

Mudde, C. (2007). Populist radical right parties in Europe. Cambridge: Cambridge University Press.

Mudde, C. (2013). Three decades of populist radical right parties in Western Europe: So what? European Journal of Political Research 52(1): 1-19.

Oesch, D. (2006). Redrawing the class map: Stratification and institutions in Britain, Germany, Sweden and Switzerland. Basingstoke: Palgrave Macmillan.

Oesch, D. (2008a). The changing shape of class voting: An individual-level analysis of party support in Britain, Germany and Switzerland. European Societies 10(3):329-355.

Oesch, D. (2008b). Explaining workers' support for right-wing populist parties in Western Europe: Evidence from Austria, Belgium, France, Norway and Switzerland. International Political Science Review 29(3): 349-373.

Oesch, D. (2013). The class basis of the cleavage between the new left and the radical right: An analysis for Austria, Denmark, Norway and Switzerland. In J. Rydgren (ed.), Class politics and the radical right. London: Routledge.

Rovny, J. (2013). Where do radical right parties stand? Position blurring in multidimensional competition. European Political Science Review 5(1): 1-26.

Rydgren, J. (ed.) (2013). Class politics and the radical right. London: Routledge.

Van der Brug, W. \& Van Spanje, J. (2009). Immigration, Europe and the 'new' cultural dimension. European Journal of Political Research 48(3): 309-334.

Address for correspondence: Daniel Oesch, Life Course and Inequality Research Centre (LINES), University of Lausanne, CH-1015 Lausanne, Switzerland.Email: daniel.oesch@unil.ch 